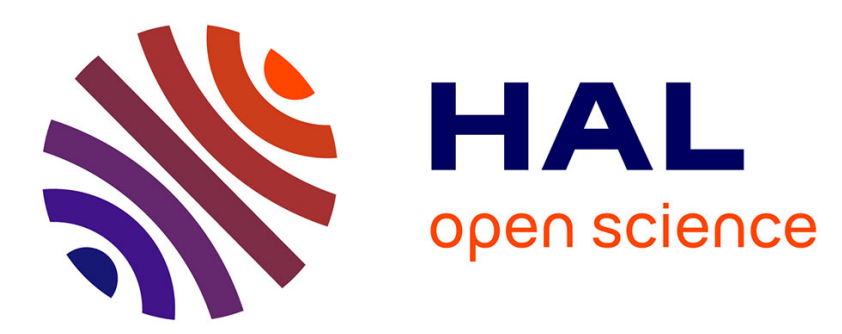

\title{
Cold adaptation across the elevation gradient in an alpine butterfly species complex
}

\author{
Gabriel Nève, Laurence Després
}

\section{To cite this version:}

Gabriel Nève, Laurence Després. Cold adaptation across the elevation gradient in an alpine butterfly species complex. Ecological Entomology, 2020, Ecological Entomology, 45 (5), pp.997-1003. 10.1111/een.12875 . hal-02553236

\section{HAL Id: hal-02553236 \\ https://hal-amu.archives-ouvertes.fr/hal-02553236}

Submitted on 24 Apr 2020

HAL is a multi-disciplinary open access archive for the deposit and dissemination of scientific research documents, whether they are published or not. The documents may come from teaching and research institutions in France or abroad, or from public or private research centers.
L'archive ouverte pluridisciplinaire HAL, est destinée au dépôt et à la diffusion de documents scientifiques de niveau recherche, publiés ou non, émanant des établissements d'enseignement et de recherche français ou étrangers, des laboratoires publics ou privés. 
Published on 23 Apr. 2020, with a few minor wording changes, in Ecological Entomology (2020), DOI: 10.1111/een.12875

COLD ADAPTATION ACROSS THE ELEVATION GRADIENT IN AN ALPINE BUTTERFLY SPECIES COMPLEX

RUNNING TITLE : WARMING UP IN BUTTERFLIES

Gabriel Nève (1) and Laurence Després (2)

(1) Aix Marseille Univ, Univ Avignon, CNRS, IRD, IMBE, Case 421, Avenue Normandie Niemen, F-13397 Marseille cedex 20, France. E-mail gabriel.neve@imbe.fr

(2) Univ. Grenoble Alpes, CNRS, LECA, F-38000 Grenoble, France. E-mail laurence.despres@univ-grenoble-alpes.fr

Correspondence :

Gabriel Nève, Aix Marseille Univ, Univ Avignon, CNRS, IRD, IMBE, Case 421, Avenue Normandie Niemen, F-13397 Marseille cedex 20, France. E-mail gabriel.neve@imbe.fr

Nève, G.; Després, L. 2020. Cold adaptation across the elevation gradient in an alpine butterfly species complex. Ecological Entomology, in press (1st April 2020)

All data are available at :

https://datadryad.org/stash/dataset/doi:10.5061/dryad.ttdz08ktn 


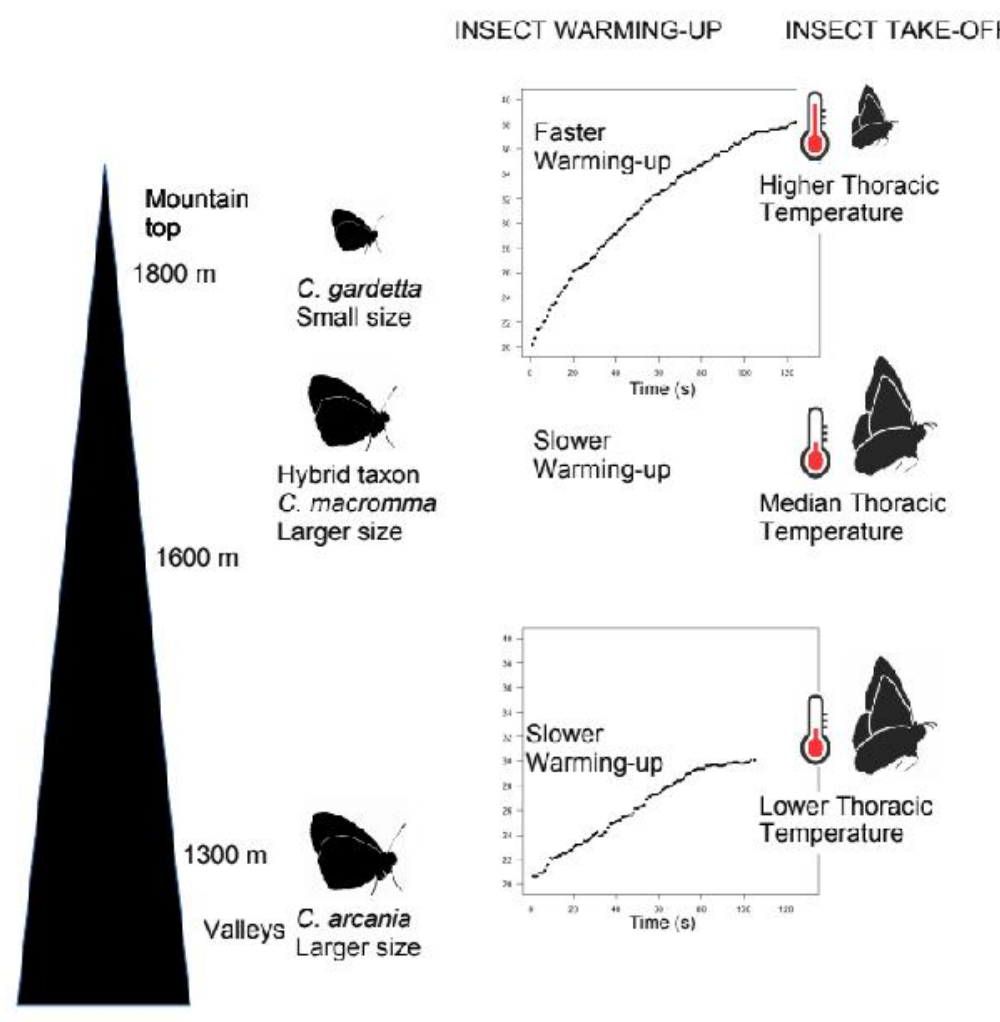

- We captured Coenonympha butterflies at different altitudes and monitored their warming-up rates and thoracic temperatures at take-off.

- Specimens of $C$. gardetta found at high altitudes were smaller, warmed up faster and took-off with higher thoracic temperatures than taxa found at lower altitudes.

- Specimens of $C$. arcania found at lower altitudes warmed-up more slowly and tookoff with a thoracic temperature lower than the specimens of $C$. gardetta and $C$. macromma. 


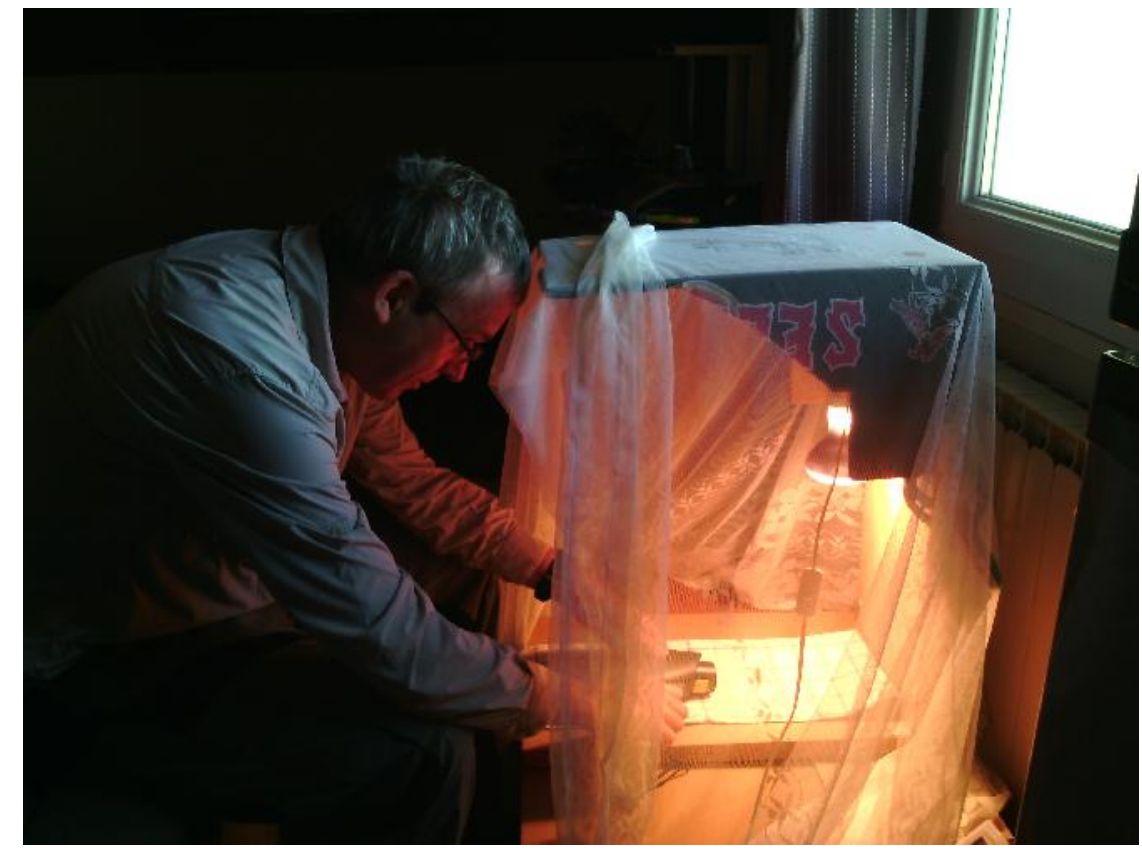

Laboratory set up: Gabriel Nève is measuring the thoracic temperature of a Coenonympha specimen as it warms up under the lamp.

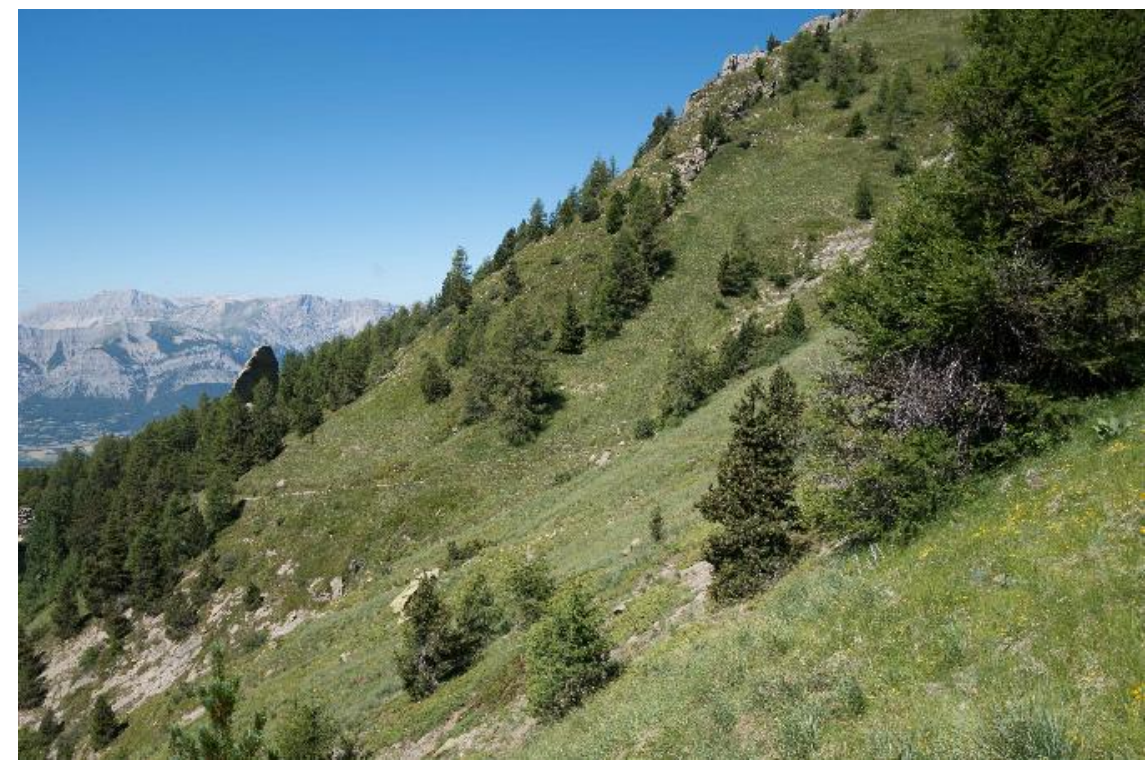

Field survey : Typical

Coenonympha macromma habitat at Chaillol 
Abstract

1.Temperature acts as a major factor on the timing of activity and behaviour in butterflies, and it might represent a key driver of butterfly diversification along elevation gradients. Under this hypothesis, local adaptation should be found along the elevation gradient, with butterflies from high elevation populations able to remain active at lower ambient temperature than those from low elevation.

2. We recorded the warming-up rate and the thoracic temperature at take-off of 123 individuals of the Alpine butterfly species complex Coenonympha arcania - C. macromma C. gardetta in controlled conditions.

3. Warming-up rate increased with elevation within $C$. arcania: high elevation males of $C$. arcania were able to warm-up more quickly, as compared to low elevation ones.

4. High elevation $C$. gardetta had a darker underwing pattern than low elevation ones. This high-elevation species was significantly smaller (lower weight and wing surface) than the two other species, and had a faster warming up rate.

5. Our results suggest that the ability to warm-up quickly and to take-flight at a high body temperature evolved adaptively in the high-altitude $C$. gardetta, and that low temperature at high altitude may explain the absence there of $C$. arcania, while the hybrid nature of $C$. macromma is probably the explanation of its elevation overlap with both other species, and its local replacement of $C$. gardetta.

Key words : Lepidoptera, Coenonympha, melanism, temperature, elevation, flight, adaptation. 
Introduction

Insect flight is one of the most energetically demanding activities in the animal kingdom, yet for many insects flight is necessary for reproduction and foraging. Moreover, flight dispersal is essential for the long-term viability of species in fragmented landscapes (Kvist et al., 2015). The thoracic muscles of insects exhibit the highest mass-specific metabolic rates known for any locomotory tissue (Dudley, 2000) and insect flight activity is strongly constrained by external temperature. Temperature is the main selective factor acting on butterfly physiology and behaviour (Clench, 1966; Wickman, 2009). Mountain regions harbour a large amount of butterfly diversity, including series of congeneric species distributed across the elevational gradient (Kleckova et al., 2014). This suggests that temperature might act as a diversifying selective pressure selecting for the ability to fly in cold conditions in high elevation populations (within species) ultimately leading to distinct, specialized alpine species. Under this hypothesis, thermal requirements for flight are expected to be lower at high than at low elevation (Advani et al. 2019), and for alpine species as compared to low elevation species (Kingsolver, 1983).

We tested this hypothesis by monitoring thoracic flight temperature (warming-up rate and take-off temperature) under controlled conditions in the three butterflies Coenonympha arcania (Linnaeus, 1761), C. gardetta (Prunner, 1798) and C. macromma (Turati \& Verity, 1911) collected at a range of elevations, and hence of mean daily temperatures. These three butterflies are distributed across the French Alps, with $C$. arcania being the only species found at low elevations and widespread in Europe. C. gardetta is an alpine species found only at high elevations $(>1500 \mathrm{~m})$ in the Alps. C. macromma results from hybridization between $C$. gardetta and C. arcania (Capblancq et al. 2015; 2019). In the southern Alps, C. macromma and C. gardetta are found above $1600 \mathrm{~m}$, while C. arcania is found mainly below $1600 \mathrm{~m}$ (Jacquet \& Bence, 2020). Generally, C. macromma has a more restricted geographical distribution than $C$. gardetta, being found only in the Southern Alps, where it locally replaces C. gardetta (Capblanc et al. 2019).

Although thoracic temperature at take-off under laboratory conditions does not directly reflect the take-off temperature in field conditions, where motivation to flight can be triggered by much more complex mechanisms than the ambient temperature, we considered this measure as a proxy for temperature at which butterfly activity is possible. Our working hypothesis is 
that take-off body temperature should be lower in the two alpine species than in the low elevation species. Within species, we expect to monitor lower take off temperature in high versus low elevation populations, if there is local adaptation to cooler temperatures at higher elevation (Angilletta, 2009). Because morphological traits such as melanism and wing load are known to interfere with insect flight ability along thermal gradients, we also measured for each specimen the total wing and body surfaces, and underwing dark surface and computed a darkness index.

Material and methods

Individual Coenonympha specimens were collected in the Massif des Ecrins, French Alps (Isère and Hautes-Alpes, Table 1). All captures using entomological nets took place between 3 and 6 July 2017. C. arcania was collected in three localities: Chaillol-Les Combettes (1275 $\mathrm{m})$, Chaillol $(1600 \mathrm{~m})$, where it flies together with C. macromma, and Notre Dame de la Salette $(1770 \mathrm{~m})$ where it flies with C. gardetta. C. macromma was collected at three elevations in Chaillol (1600 m, $1850 \mathrm{~m}$ and $2000 \mathrm{~m})$. C. gardetta was collected in Notre Dame de la Salette $(1800 \mathrm{~m})$ and in Ailefroide $(1875 \mathrm{~m})$. Local elevation was taken as a proxy for local temperature experienced by butterflies in the field. Annual mean temperature in this part of the Alps was previously shown to be strongly correlated with elevation $(r=.96)$ and to decrease linearly by $0.3 \mathrm{~m}$ per $100 \mathrm{~m}$ of elevation (Gallou et al. 2017). For each locality, we extracted the 19 bioclimatic variables averaged over 30 years (1960-1990) from the WorldClim database (http://www.worldclim.org; Hijmans et al. 2005): all were strongly correlated with altitude (supplementary data Fig. S1) either negatively for mean temperature, or positively for total precipitation, ranging respectively from $6.7-\mathrm{C}$ and $1015 \mathrm{~mm}$ at $1275 \mathrm{~m}$ to $2.5 \mathrm{~m} \mathrm{C}$ and $1356 \mathrm{~mm}$ at $2000 \mathrm{~m}$ (Table 1 ).

Upon capture, butterflies were individually put into glassine envelopes and cooled to ca. $11 \mathrm{mC}$ in a portable fridge. The same day, in a room at ambient temperature ( 22 to $25 \mathbf{m}$ ), each specimen was taken out of the fridge and placed on a piece of cotton under a $150 \mathrm{~W}$ neodynium daylight lamp, which has a measured light emission spectrum from 100 to $1400 \mathrm{~nm}$, giving an irradiance of ca. $280 \mathrm{~W} / \mathrm{m}^{2}$ at the butterfly level. Although this irradiance is lower than the irradiance at midday that the butterflies would experience in their environment, previous experiments showed that most butterflies of various species display basking behaviour in these conditions before taking-off (Nève, 2010, Nève and Hall 2016). 
The thoracic temperature of each specimen was monitored with a testo $(895$ IR thermometer with the emissivity set at $\varepsilon=0.95$, and the temperature was automatically recorded into a computer database, one datum per second. A previous experiment has shown that the temperature inside the thorax was ca. $1.3^{\circ} \mathrm{C}$ warmer than the one measured at the surface, with a low variance of this difference (Nève and IIall, 2016). The take-off temperature was the last temperature recorded before the butterfly spontancously took off. A 4-th degrec curve was fitted to the raw data, and its slope was used to estimate the warming-up rate at $26^{\circ} \mathrm{C}$, in ${ }^{\circ} \mathrm{C} \mathrm{s}^{-1}$ (suppl. material Fig. S2). Out of a total of 123 butterflies captured in the field, 107 (77 males and 30 females) took off in the laboratory. Warming-up and take-off were monitored once per individual. The fifteen individuals that did not take ofl in the laboratory were discarded from all analyses. Immediately after the experiment, each individual was weighted to the nearest $\mathrm{mg}$ using a precision balance (Mettler Toledo $0.1 \mathrm{mg}$ precision). $\Lambda \mathrm{ll}$ specimens were subsequently killed in a $-20^{\circ} \mathrm{C}$ freezer and set dry to be photographed with a Canon $80 \mathrm{D}$ reflex camera set with a Canon $60 \mathrm{~mm} \mathrm{f} / 2.8$ macro lens, using constant camera settings and light conditions. The photographs were then analysed by ImageJ v1.5 (Ferreira and Rasband, 2012) to measure the total wing and body areas, and underwing dark surface and darkness index. The underwing was chosen as Coenonympha butterllies bask only with their underwings (Heinrich, 1986; pers. obs.). The darkness index $D_{i}$ was estimated using

$$
D_{i}=\frac{W-G_{w}}{W-B},
$$

with $G_{w}$, the mean grey value of the dark underwing area, $B$, the grey value of a black standard and $W$ the grey value of a white standard (supplementary data Fig. S3), which is the method already used by De Keyser et al. (2015). Individual wing loading was computed as the ratio between the total mass and the total wing and body surface (Dudley 1990). All statistical analyses were performed using R (R Core Team, 2013). We used multiple linear regression models to test for the effects of elevation, species, sex and all possible interactions on thoracic Ilight temperature at take-ofl and on warming-up rate at $26^{\circ} \mathrm{C}$, and performed stepwise model selection based on $\Lambda$ kaike information criterion $(\Lambda \mathrm{IC})$. To estimate pairwise differences between sex and between species, we performed Tukey's post hoc tests. Critical pvalues were set at 0.05 . We further tested using linear regressions the effects of elevation, species and sex on weight, wing surface, wing load, and darkness index, and all pairwise 
Pearson's correlations, in order to better understand how species- and sex-specific morphological traits relate to potentially adaptive physiological traits. Residuals were checked using the Shapiro-Wilk normality test, and did not deviate from normality.

Results

Thoracic take-off temperatures of Coenonympha individuals varied from $27.0 \mathrm{~m}$ to $43.1 \mathrm{~m} \mathbf{C}$, and did not significantly differ among the three species $\left(\mathrm{F}_{2,104}=0.87, \mathrm{P}=0.418\right)$. Elevation of capture was the only significant effect on thoracic take-off temperature remaining after stepwise selection on elevation, sex and species and all their possible interactions. This effect was significant for females $\left(\mathrm{F}_{1,28}, \mathrm{P}=0.021\right.$, Fig. 1) but not for males $\left(\mathrm{F}_{1,75}=3.307, \mathrm{P}=0.073\right)$.

The darkness index did not vary significantly among the three tested species, neither for males $\left(\mathrm{F}_{1,75}=0.37, \mathrm{P}=0.54\right)$ nor for females $\left(\mathrm{F}_{1,28}=1.95, \mathrm{P}=0.217\right)$. For neither sex did it change with altitude in C. arcania and C. macromma, but darkness increased with altitude for both males and females in C. gardetta (Fig. 2).

The warming-up rate at 26 $\mathbf{m}$ was not significantly correlated with darkness index, neither globally for males $(\mathrm{P}=0.95)$ nor females $(\mathrm{P}=0.35)$, nor taking each sex and species separately (all $\mathrm{P}>0.1$ ). The warming-up rate at $26 \mathrm{~m}$ was positively correlated with elevation in $C$. $\operatorname{arcania}(\mathrm{P}=0.04)$, and negatively in $C$. gardetta males $(\mathrm{P}=0.03$; Fig. 3$)$ and females $(\mathrm{P}=0.02)$. C. gardetta had significantly faster warming-up rate than the other two species (Table 2). There was a significant negative effect of weight on warming up-rate $\left(\mathrm{F}_{1,104}=16.29, \mathrm{P}<\right.$ 0.001), and females had significantly higher weight and lower warming-up rate than males $\left(\mathrm{F}_{1,105}=314, P<0.001\right.$ and $\mathrm{F}_{1,105}=31.5, P<0.001$ respectively $)$.

The wing loading of females was about twice that of the males (mean wing loading females : $0.091 \mathrm{~g} . \mathrm{cm}^{-2}$; mean wing loading males : $0.045 \mathrm{~g} . \mathrm{cm}^{-2}, \mathrm{t}_{32}=-13.7, P<0.001$, Table 4). The wing loadings of the three species were similar for females $\left(\mathrm{F}_{2,27}=0.956, \mathrm{P}=0.397\right)$, but did vary significantly among males of the three species $\left(\mathrm{F}_{2,74}=4.39, \mathrm{P}=0.016\right)$, with $C$. gardetta having values similar to the highest values observed in C. arcania, and C. macromma to the lowest (Fig. 4). 


\section{Discussion}

Our experimental design allowed us to test the thoracic temperature from which flight is possible, rather than assessing the thoracic temperature at which individuals usually fly in natura. The highest recorded take-off thoracic temperatures of these alpine butterflies $(43-\mathrm{C})$ were higher than those previously measured the same way for a set of Mediterranean species, where the highest recorded temperature was $39.9 \mathbf{m}$, and only five of the forty species had minimum values lower than the $27 \mathbf{m}$ recorded in the present study (Nève, 2010).

In contrast to our initial hypothesis, thoracic take-off temperature was not significantly different across species, and increased with elevation but only for females. High elevation butterflies tend to warm up more rapidly and to take-off at higher temperatures than low elevation ones, in contrast with the results obtained by Advani et al. (2019) on Melitea cinxia. The ability to warm up quickly could be advantageous at high elevation, where the length of favourable period for flight is reduced. Indeed, not only is the length of the reproductive period reduced at high elevation, but also the duration of each flight bout is more often compromised by clouds and/or wind (Cormont et al., 2011) and heat loss (Advani et al. 2019). In this context, being able to warm-up rapidly, as soon as solar radiation increases, might be a pre-requisite for butterfly survival at high elevation, as observed in the Lapland butterflies Colias nastes and C. hecla (Majerus 1998, p 160). In support of this hypothesis, in a close relative to our study species, Coenonympha pamphilus, cloudiness had negative effects on flight propensity, and wind speed showed a negative effect on net displacement in the field (Cormont et al., 2011).

The thermal melanism hypothesis states that dark individuals (i.e. lower reflectance) heat up faster than light individuals at a given solar radiation (Clusella Trullas et al., 2007). A metaanalysis performed on 473 European butterfly and dragonfly species has shown a direct link between temperature and darkness, dark-colored insect species being favored in cooler climates (Zeuss et al., 2014). In addition to a better conversion of solar radiation to body heat, darker individuals at high elevation could benefit from a more efficient protection against UV light (Hu et al., 2013). In the present study, only C. gardetta showed darker individuals at higher elevation, both in males and females. This species is also smaller than the other two species (Table 4, Capblancq et al., 2015, Lafranchis, 2000). Decreased body size with elevation was found in many other insect species and there is strong empirical evidence for a 
converse of Bergmann's Rule in ectotherms (Mousseau 1997; Gaston \& Shown 2013; Klok \& Harrison 2013). While both melanism and small size are traits likely favouring more rapid warming-up, we observed a negative relationship between warming-up rate and altitude in $C$. gardetta. This could be due to the limited elevation range sampled for this species (1800$1875 \mathrm{~m})$, sampled at two distant sites $(36 \mathrm{~km})$ with different local topographies east and west of the Ecrins massif. Within $C$. arcania, specimens were sampled along an elevational gradient in Chaillol, and although there was no melanism increase with elevation, we observed a warming up increase with elevation, as expected if warming up was under local selection along the environmental gradient. The low temperature at high elevation may preclude the presence of $C$. arcania there. The hybrid origin of $C$. macromma which genome is a mixture of $70 \% / 30 \%$ C. arcania/C. gardetta genomes (Capblancq et al 2015) may explain why this species is able to survive at high elevation in Chaillol and generally showed little variation of measured traits among its elevation range.

In addition to temperature, many other factors may constrain butterfly flight at high elevation, including predation pressure, oxygen and energy availability (Fountain et al., 2016), wind and radiation (Cormont et al., 2011). Wing loading is positively correlated with speed and manoeuvrability (Tennekes, 2009), and we observed that the wing loading increases with elevation, regardless of species (Table 3). Furthermore, C. gardetta males had a higher wing loading than the other species, suggesting different flying strategies for high and low elevation populations/species, possibly in relation to abiotic (e.g., wind) constrains on flight at higher elevation. Interestingly, males and females seem to have different strategies, as revealed by significant interactions between sex and elevation. Females have a significantly greater weight than males, and presumably different energetic/metabolic constrains in link with oviposition requirements (Kvist et al., 2015). In support of the hypothesis of sexdependent strategies in butterflies, both flight performance and flight metabolic rate were shown to respond differently to temperature in males and females in Pararge aegeria (Van Dyck and Holveck, 2016), and heating rate ability was found to be sex-dependant in Pieris brassicae (Ducatez et al., 2013).

In conclusion, we show that warming-up rate increases along the elevational gradient within C. arcania, and among species, suggesting that adaptation to cold is a central trait in species diversification in this alpine butterfly species complex. Further work is needed to fully 
understand the trade-offs underlying body and wing colour, thermoregulation, flight ability and other butterfly traits such as mate-signalling, predator-signalling, and resistance to disease along the elevational gradient. We show here that on top of flight thoracic temperature per se, the warming-up variation is also a key trait to be taken into account in the understanding of thermal biology of butterflies and adaptation to elevation.

\section{Acknowledgments}

We thank Vincent Pearlstein, Charlotte Millac and Marine Fournillier who assisted in the field work. Alain Thiéry lent us the infra-red thermometer. The Parc National des Ecrins allowed us to work partly within the Park.

Competing interest

No competing interests declared.

Funding

Both authors are supported by the French Ministry for Higher Education and Research.

Author contributions

Both authors participated in the field work and in the indoors experiments. They analysed the data and wrote the manuscript.

Supporting Information

Additional supporting information may be found online in the Supporting Information section at the end of the article.

Data availability

The relevant data set, and all individual photographs have been deposited in DRYAD under doi:10.5061/dryad.ttdz08ktn. The collection of butterfly specimens used in this study has been deposited at the Marseille Natural History Museum. 


\section{References}

Advani, N.K., Parmesan, C. \& Singer, M.C. (2019). Takeoff temperatures in Melitaea cinxia butterflies from latitudinal and elevational range limits: a potential adaptation to solar irradiance. Ecological Entomology 44, 389-396.

Angilletta, M. (2009). Thermal Adaptation : A Theoretical and Empirical Synthesis. Oxford ; Oxford University Press.

Bence, S., Jacquier, C. (2020). Coenonympha arcania. In: Atlas des Papillons de Jour \& Zygènes de ProvenceAlpes-Côte d'Azur. (ed. S. Bence and S. Richaud), pp. 437. Gap: Conservatoire d'espaces naturels de ProvenceAlpes-Côte d'Azur \& Le Naturographe.

Capblancq, T., Després, L., Rioux, D. \& Mavárez, J. (2015) Hybridization promotes speciation in Coenonympha butterflies. Molecular Ecology 24, 6209-6222.

Capblancq, T., Mavárez, J., Rioux, D., Després, L. (2019) Speciation with gene flow: Evidence from a complex of alpine butterflies (Coenonympha , Satyridae). Ecology and Evolution 9, 6444-6457.

Clench, H.K. (1966) Behavioral thermoregulation in butterflies. Ecology 47, 1021-1034.

Clusella Trullas, S., van Wyk, J.H. \& Spotila, J.R. (2007) Thermal melanism in ectotherms. Journal of Thermal Biology 32, 235-245.

Cormont, A., Malinowska, A.H., Kostenko, O., Radchuk, V., Hemerik, L., WallisDeVries, M.F. \& Verboom, J. (2011) Effect of local weather on butterfly flight behaviour, movement, and colonization: significance for dispersal under climate change. Biodiversity and Conservation 20, 483-503.

De Keyser, R., Breuker, C.J., Hails, R.S., Dennis, R.L.H. \& Shreeve, T.G. (2015). Why small is beautiful: wing colour is free from thermoregulatory constraint in the small Lycaenid Butterfly, Polyommatus icarus. PLoS One 10, e0122623.

Ducatez, S., Baguette, M., Trochet, A., Chaput-Bardy, A., Legrand, D., Stevens, V. \& Fréville, H. (2013) Flight endurance and heating rate vary with both latitude and habitat connectivity in a butterfly species. Oikos 122, 601-611.

Dudley, R. (1990) Biomechanics of flight in neotropical butterflies: morphometrics and kinematics. Journal of Experimental Biology 150, 37-53.

Dudley, R. (2000) The Biomechanics of Insect Flight: Form, Function, Evolution. Princeton, NJ : Princeton University Press.

Ferreira, T. \& Rasband, W.S. (2012). ImageJ User Guide - IJ 1.46, imagej.nih.gov/ij/docs/guide/, Accessed 3 Jan 2014

Fountain, T., Melvin, R.G., Ikonen, S., Ruokolainen, A., Woestmann, L., Hietakangas, V. \& Hanski, I. (2016) Oxygen and energy availability interact to determine flight performance in the Glanville fritillary butterfly. Journal of Experimental Biology 219, 1488-1494.

Gallou, A., Baillet, Y., Ficetola, G.F. \& Després, L. (2017) Elevational gradient and human effects on butterfly species richness in the French Alps. Ecology and Evolution 7, 3672-3681.

Heinrich, B. (1986) Thermoregulation and flight activity of a Satyrine, Coenonympha inornata (Lepidoptera: Satyridae). Ecology, 67, 594-597.

Hijmans, R.J., Cameron, S.E., Parra, J.L., Jones, P.G. \& Jarvis, A. (2005) Very high resolution interpolated climate surfaces for global land areas. International Journal of Climatology, 25, 1965-1978.

Hu, Y.G., Shen, Y.H., Zhang, Z. \& Shi, G.Q. (2013) Melanin and urate act to prevent ultraviolet damage in the integument of the silkworm, Bombyx mori. Archives of Insect Biochemistry and Physiology 83, 41-55.

Kingsolver, J.G. (1983) Thermoregulation and flight in Colias butterflies: elevational patterns and mechanistic limitations. Ecology 64, 534-545. 
Kleckova, I., Konvicka, M. and Klecka, J. (2014) Thermoregulation and microhabitat use in mountain butterflies of the genus Erebia: Importance of fine-scale habitat heterogeneity. Journal of Thermal Biology, 41, $50-58$.

Kvist, J., Mattila, A.L.K., Somervuo, P., Ahola, V., Koskinen, P., Paulin, L., Salmela, L., Fountain, T., Rastas, P., Ruokolainen, A., Taipale, M., Holm, L., Auvinen, P., Lehtonen, R., Frilander, M.J. \& Hanski, I. (2015) Flight-induced changes in gene expression in the Glanville fritillary butterfly. Molecular Ecology 24, 4886-4900.

Lafranchis, T. (2000) Les papillons de jour de France, Belgique et Luxembourg et leurs chenilles. Mèze: Biotope.

Majerus, M.E.N. (1998) Melanism: Evolution in Action. Oxford: Oxford University Press.

Mousseau, T.A. (1997) Ectotherms follow the converse to Bergmann's Rule. Evolution 51, 630-632.

Nève G. (2010) Variation of flight thorax temperature among Mediterranean butterflies. Entomologia Romanica 15: $21-24$

Nève, G. \& Hall, C. (2016) Variation of thorax flight temperature among twenty Australian butterflies (Lepidoptera: Papilionidae, Nymphalidae, Pieridae, Hesperiidae, Lycaenidae). European Journal of Entomology, 113, 571-578.

R Core Team (2013) R: A language and environment for statistical computing. Vienna: R Foundation for Statistical Computing. Available from http://www.r-project.org.

Tennekes H. (2009). The Simple Science of Flight: From Insects to Jumbo Jets. Cambridge, Mass.: MIT Press.

Van Dyck, H. \& Holveck, M.-J. (2016) Ecotypic differentiation matters for latitudinal variation in energy metabolism and flight performance in a butterfly under climate change. Scientific Reports 6 : 36941.

Wickman, P.O. (2009) Thermoregulation and habitat use in butterflies. In Ecology of Butterflies in Europe (ed. J. Settele, T. Shreeve, M. Konvicka, and H. Van Dyck), pp. 55-61. Cambridge: Cambridge University Press.

Zeuss, D., Brandl, R., Braendle, M., Rahbek, C. \& Brunzel, S. (2014) Global warming favours light-coloured insects in Europe. Nature Communication 5, 3874.

Gaston, K.J. \& Chown, S.L. (2013) Macroecological patterns in insect body size. In Animal Body Size: Linking Pattern and Process across Space, Time and Taxonomic Group (ed. F.A. Smith \& S.K. Lyons), pp 13-61. University of Chicago Press, Chicago, Illinois.

Klok, C.J. \& Harrison, J.F. (2013) The temperature size rule in arthropods: independent of macroenvironmental variables but size dependent. Integrative and Comparative Biology, 53, 557-570. 
Table 1. Numbers of tested specimens, and their capture locations.

\begin{tabular}{|c|c|c|c|c|c|c|}
\hline Species & Location & $\begin{array}{l}\text { Alti- } \\
\text { tude } \\
(\mathrm{m})\end{array}$ & $\begin{array}{l}\text { Mean tem- } \\
\text { perature } \\
(\mathbf{E})\end{array}$ & $\begin{array}{l}\text { Annual pre- } \\
\text { cipitation } \\
(\mathrm{mm})\end{array}$ & $\begin{array}{l}\text { Number } \\
\text { of males }\end{array}$ & $\begin{array}{l}\text { Number of } \\
\text { females }\end{array}$ \\
\hline \multirow{3}{*}{$\begin{array}{c}\text { Coenonympha } \\
\text { arcania }\end{array}$} & $\begin{array}{l}\text { Chaillol-Les } \\
\text { Combettes }\end{array}$ & 1275 & 6.7 & 1015 & 12 & 8 \\
\hline & Chaillol & 1600 & 5.3 & 1118 & 4 & 1 \\
\hline & $\begin{array}{l}\text { Notre- } \\
\text { Dame-de- } \\
\text { la-Salette }\end{array}$ & 1770 & 4.9 & 1181 & 14 & 3 \\
\hline \multirow{3}{*}{$\begin{array}{c}\text { Coenonympha } \\
\text { macromma }\end{array}$} & Chaillol & 1600 & 5.3 & 1118 & 1 & 2 \\
\hline & Chaillol & 1850 & 4.2 & 1208 & 15 & 2 \\
\hline & Chaillol & 2000 & 2.5 & 1356 & 15 & 3 \\
\hline \multirow[t]{2}{*}{$\begin{array}{l}\text { Coenonympha } \\
\text { gardetta }\end{array}$} & $\begin{array}{l}\text { Notre- } \\
\text { Dame-de- } \\
\text { la-Salette }\end{array}$ & 1800 & 4.9 & 1181 & 9 & 6 \\
\hline & Ailefroide & 1875 & 2.8 & 1365 & 7 & 5 \\
\hline Total & & & & & 77 & 30 \\
\hline
\end{tabular}


Table 2 Effects of elevation, sex, and species on warming-up rate for best linear model, based on AIC.

\begin{tabular}{|c|c|c|c|c|c|}
\hline \multirow[b]{2}{*}{ Effect } & \multicolumn{5}{|c|}{ Warming-up rate } \\
\hline & Estimate & SD & $\mathbf{t}$ & P-value & \\
\hline Elevation & $1.0210^{-4}$ & $3.7610^{-5}$ & 2.716 & 0.0078 & $* *$ \\
\hline Sex & $6.9210^{-2}$ & $1.2710^{-2}$ & 5.466 & $3.4510^{-7}$ & $* * *$ \\
\hline Species & 1.55 & 0,545 & 2.85 & 0.00533 & $* *$ \\
\hline Elevation $x$ Species & $-8.5610^{-4}$ & $2.9810^{-4}$ & -2.875 & 0.00495 & $* *$ \\
\hline
\end{tabular}

$\mathrm{x}$ : interaction between factors.

Table 3 Effects of elevation, sex, and species on wing loading for best linear model, based on AIC.

\begin{tabular}{|c|c|c|c|c|c|}
\hline \multirow[b]{2}{*}{ Effect } & \multicolumn{5}{|c|}{ Wing loading } \\
\hline & Estimate & SD & $\mathbf{t}$ & P-value & \\
\hline Elevation & $6.9010^{-5}$ & $1.1710^{-5}$ & 5.888 & $5.87 \mathrm{E}-08$ & $* * *$ \\
\hline Species & 0.467 & 0.132 & 3.537 & 0.000628 & $* * *$ \\
\hline Elevation $\mathrm{x}$ sex & $-4.9310^{-5}$ & $1.3710^{-5}$ & -3.61 & 0.000491 & $* * *$ \\
\hline Elevation $\mathrm{x}$ species & $-2.6610^{-4}$ & $7.2310^{-5}$ & -3.683 & 0.000382 & $* * *$ \\
\hline Sex x Species & $-0,398$ & 0.171 & -2.322 & 0.022361 & $*$ \\
\hline Elevation $x$ Sex $x$ Species & $2.2710^{-4}$ & $9.3810^{-5}$ & 2.424 & 0.017263 & * \\
\hline
\end{tabular}

$\mathrm{x}$ : interaction between factors.

Table 4. Traits measured on the three species, for males and females. The median value is given with minimum and maximum values in brackets.

\begin{tabular}{|c|c|c|c|c|c|}
\hline Species & Sex & $\mathrm{N}$ & weight(mg) & Total suface $\left(\mathrm{mm}^{2}\right)$ & $\begin{array}{l}\text { Wing loading } \\
\left(\mathrm{mg} \cdot \mathrm{mm}^{-2}\right)\end{array}$ \\
\hline C. arcania & Males & 30 & $23.1(14.7,32.0)$ & $495(397,605)$ & $0.046(0.029,0.059)$ \\
\hline C. arcania & Females & 12 & $43.4(33.3,66.5)$ & $550(382,649)$ & $0.081(0.065,0.130)$ \\
\hline C. macromma & Males & 31 & $19.1(13.0,27.3)$ & $464(383,555)$ & $0.042(0.031,0.055)$ \\
\hline C. macromma & Females & 7 & $43.1(35.8,57.7)$ & $448(398,545)$ & $0.100(0.077,0.116)$ \\
\hline C. gardetia & Males & 16 & $19.6(17.4,24.2)$ & $410(374,483)$ & $0.048(0.043,0.058)$ \\
\hline C. gardetia & Females & 11 & $40.4(31.1,53.6)$ & $451(385,514)$ & $0.089(0.069,0.117)$ \\
\hline
\end{tabular}



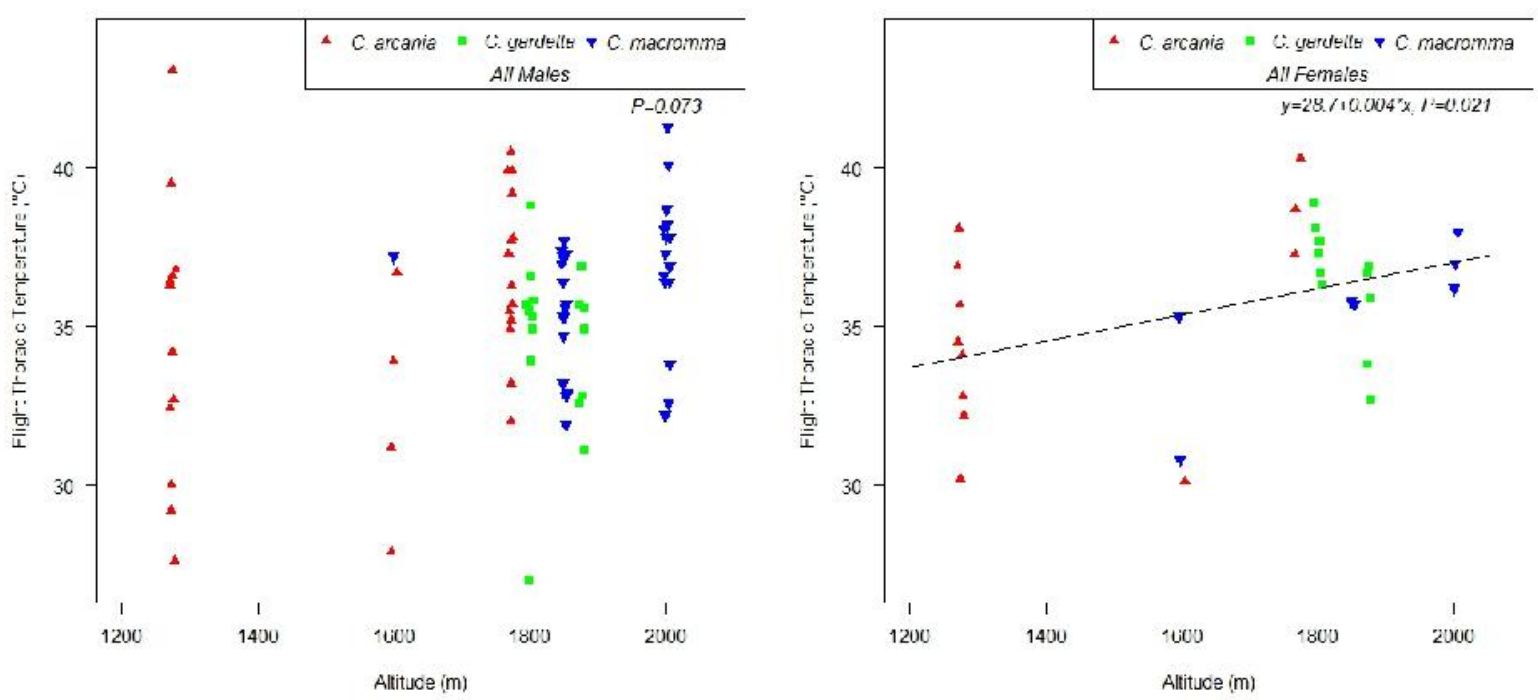

Fig. 1. Thoracic temperature (in ${ }^{\circ} \mathrm{C}$ ) at take-off as a function of capture elevation (in $\mathrm{m}$ a.s.l.), for Coenonympha males $(n=77$ ) and females $(n=30)$. The regression is significantly positive only for females. 

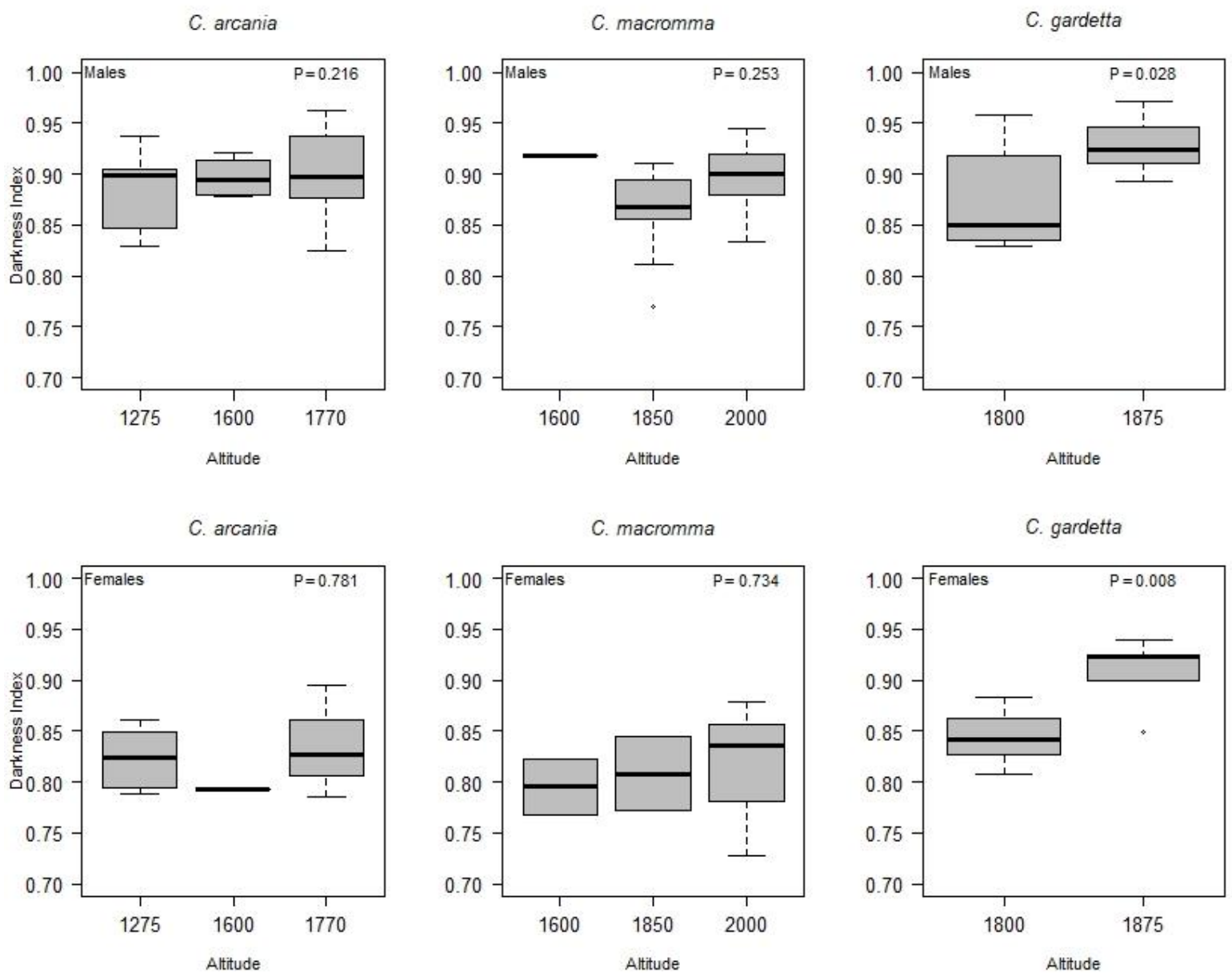

Fig. 2. Darkness index according to capture elevation (in $\mathrm{m}$ a.s.l.) in the three Coenonympha species. The individuals are darker as the elevation increases in C. gardetia males and females. 

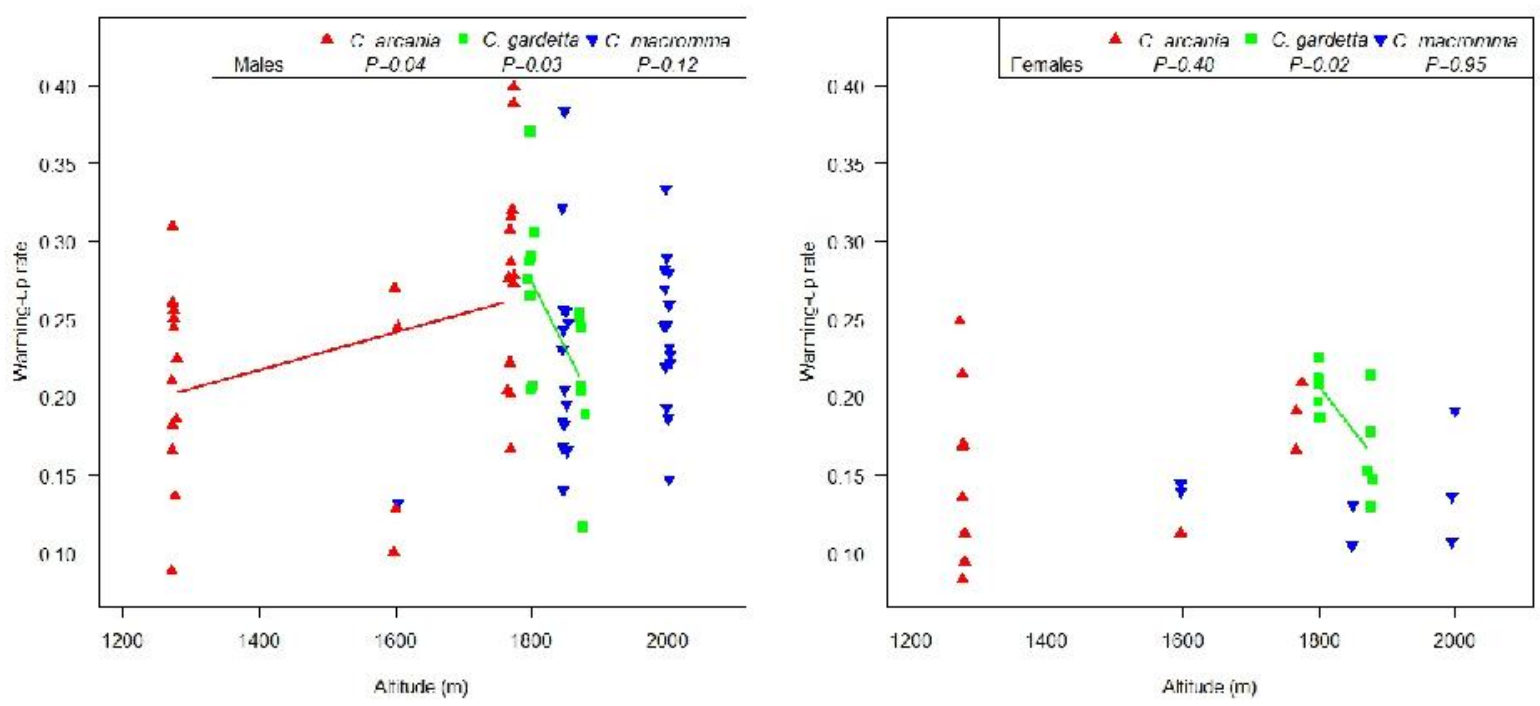

Fig. 3. Warming-up rate (in ${ }^{\circ} \mathrm{C} \mathrm{s}^{-1}$ ) as a function of the elevation (in $\mathrm{m}$ a.s.I.) at which the individuals were captured. The relationship is positive and significant for $\mathrm{C}$. arcania males $\left(F_{1,28}=4.75, P=0.04\right)$, and negative and significant for $C$. gardetia males $\left(t_{13}=2.50, P=0.03\right)$ and females $\left(t_{9}=2.94, P=0.02\right)$.
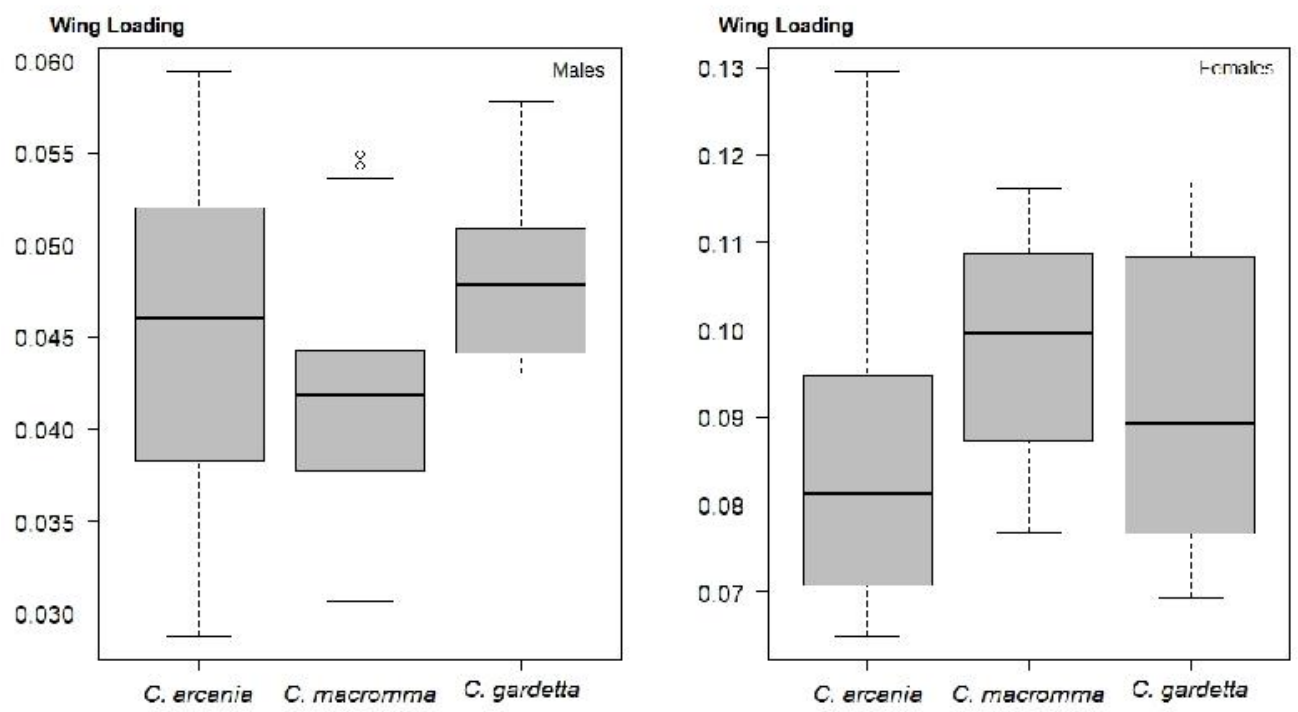

Fig. 4. Wing loading (in $\mathrm{mg} \mathrm{mm}^{-2}$ ) of specimens of the three species. The horizontal thick lines depicts the median values, the boxes show the 25 and $75 \%$ quartiles, and the whiskers the full range if it falls within 1.5 times $25-75 \%$ range; otherwise outliers are shown as small circles. $M$ ales of the three species differ significantly in their wing loadings $\left(F_{2,74}=4.39\right.$, $P=0.016)$, but females of the three species show no significant differences $\left(F_{2,27}=0.956\right.$, $P=0.397)$. 


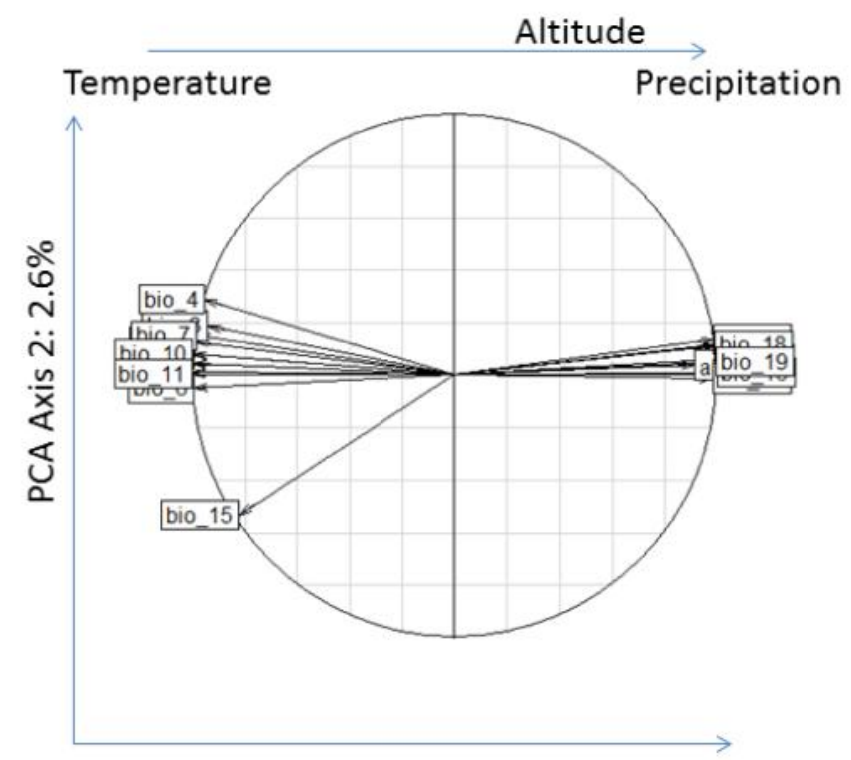

PCA Axis 1: $95.4 \%$

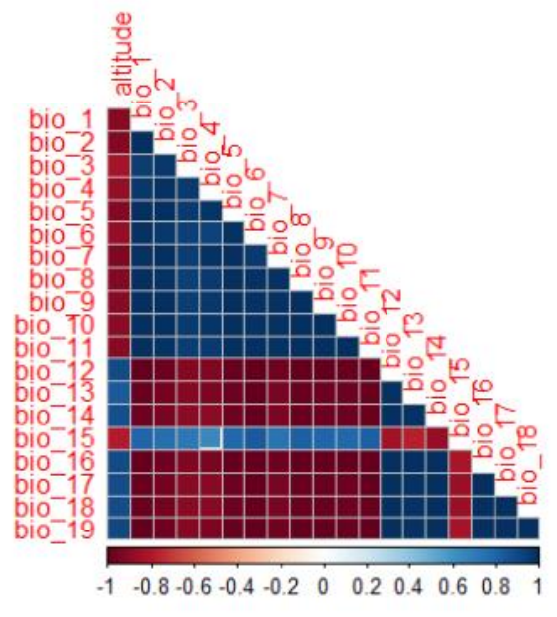

Pairwise Pearson's correlations

Fig. S1. Correlation circle and all pairwise Pearson's correlations between altitude and the 19 bioclimatic variables from WorldClim database for the sampled localities. $\Lambda$ ll the bioclimatic variables are strongly correlated to altitude (first axis: $95.4 \%$ of total variation), positively (precipitation-derived bioclimatic variables) or negatively (temperature-derived bioclimatic variables). bio_1 $=\Lambda$ nnual Mean Temperature; bio_2 $=$ Mean Diurnal Range (Mean of monthly $(\max$ temp $-\min$ temp) ); bio_ $3=$ Isothermality (bio_ $2 /$ bio_ 7$)(* 100)$; bio_ $4=$ Temperature Seasonality (standard deviation *100); bio_5 $=$ Max Temperature of Warmest Month; bio_6 = Min Temperature of Coldest Month; bio_ $7=$ Temperature $\Lambda$ nnual Range (bio_5-bio_6); bio_8 = Mcan Temperature of Wettest Quarter; bio_9 = Mcan l'emperature of Driest Quarter; bio_10 = Mean Temperature of Warmest Quarter; bio_11 = Mean Temperature of Coldest Quarter; bio_12 = Annual Precipitation; bio_13 = Precipitation of Wettest Month; bio $14=$ Precipitation of Dricst Month; bio_15 = Precipitation Scasonality (Cocfficient of Variation); bio $16=$ Precipitation of Wettest Quarter; bio $17=$ Precipitation of Driest Quarter; bio_18 = Precipitation of Warmest Quarter; bio_19 = Precipitation of Coldest Quarter 


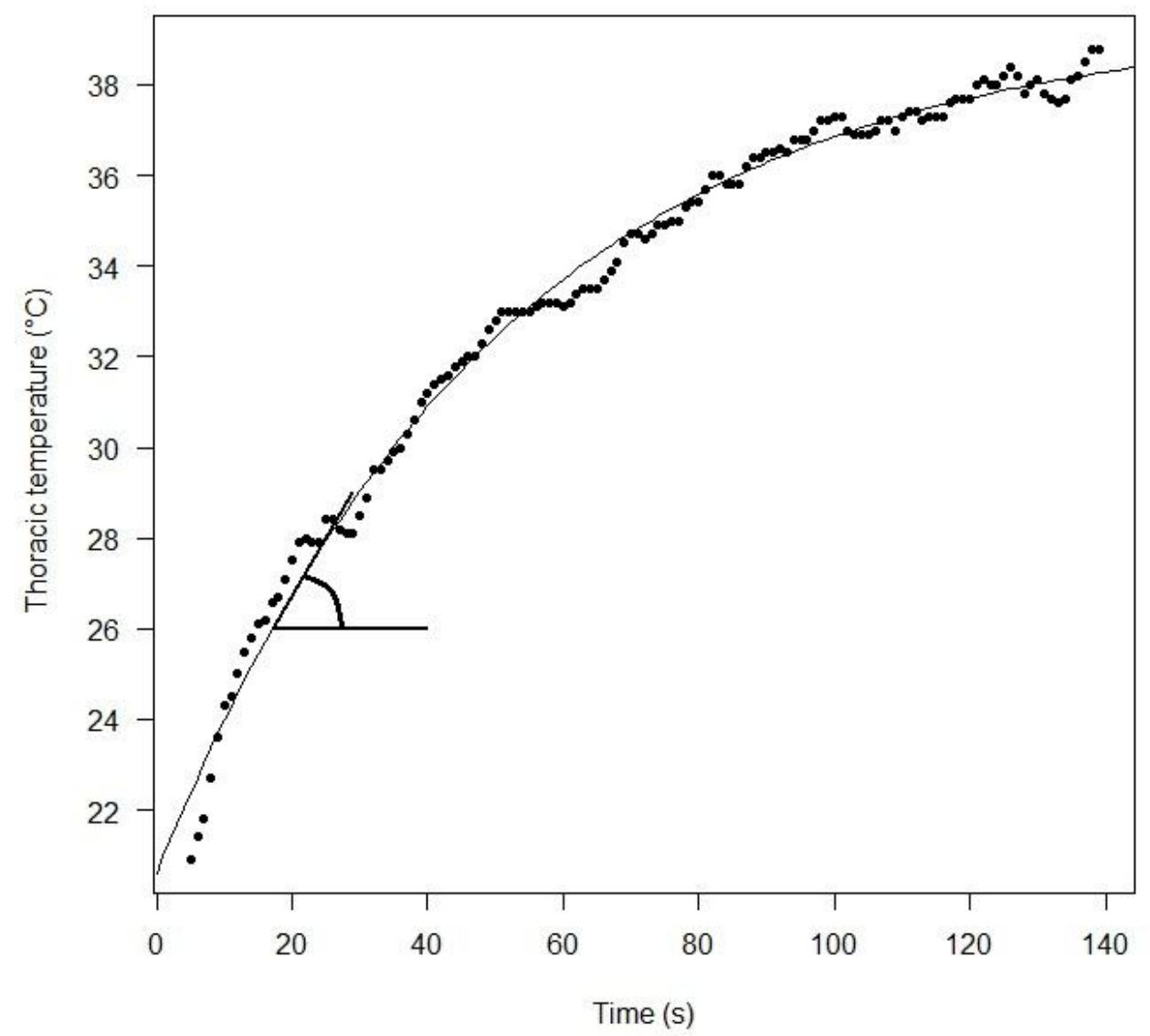

Fig. S2. Example of the warming-up curve of an individual Coenonympha gardetta. The warming-up rate was estimated as the slope of the $4^{\text {th }}$ degree best fit curve at $26 \mathrm{C}$. It is estimated here as $0.31 \mathrm{C} \mathrm{s}^{-1}$. 


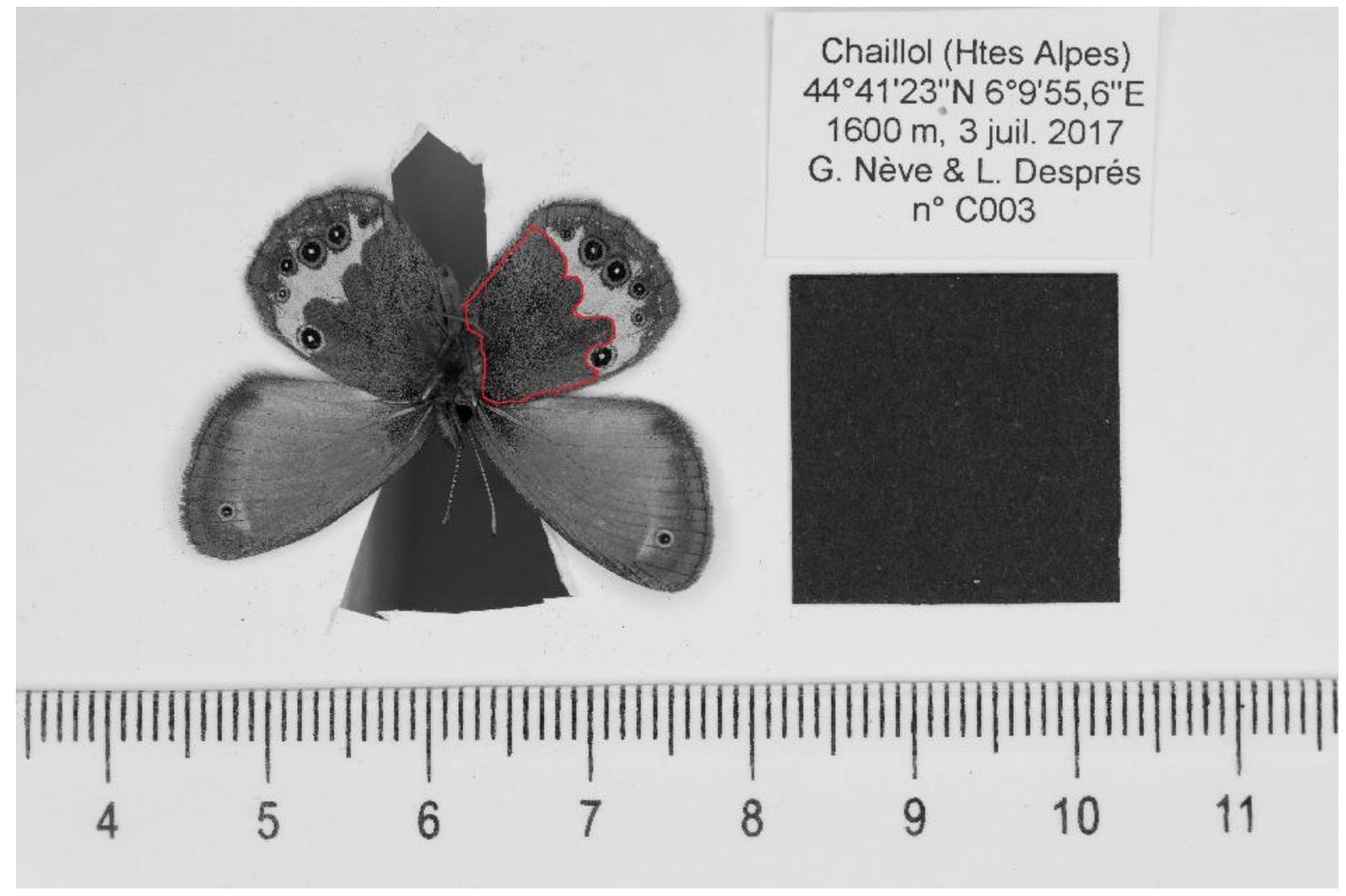

Fig. S3. Photograph of Coenonympha arcania specimen C003. The considered black underwing area, here estimated at $66 \mathrm{~mm}^{2}$, is outlined in red on the right underwing. The black square is a $20 \times 20 \mathrm{~mm}$ reference. The black square and the white background are black and white standards respectively; their raw measured grey values are 43 and 222 respectively, while the dark underwing area shows a 65 grey value. The specimen's darkness index was thus computed as $(222-65) /(222-43)=0.88$. 